\title{
DILEMA BIROKRASI DALAM DEMOCRATIC GOVERNANCE
}

\author{
I Wayan Winarsa \\ Fakultas Ilmu Sosial dan Ilmu Politik Universitas Mahendradatta Denpasar \\ E-mail: iwayanwinarsa10@gmail.com
}

\begin{abstract}
Abstrak - Pengelolaan negara/publik yang bersih dari korupsi, kolusi, nepotisme, pengelolaan sumberdaya negara/publik haruslah transparan, terbuka, lebih dari itu setiap warga negara diberi akses untuk ikut mempengaruhi jalannya pengelolaan tersebut---partisipasi. Instansi-instansi publik perlu diawasi misalnya oleh Transparency International untuk cakupan global ataupun Indonesian Corruption Watch untuk cakupan nasional. Sekarang kita sudah mengenal banyak sekali " anjing pengawas " seperti itu, termasuk yang bercakupan kabupaten /kota atau bahkan desa/kampung. Good governance, dengan demikian identik dengan transparansi dan partisipasi-democratic governance. Termasuk di dalamnya rule of law ( rechtsstaatlichkeit dan Berechenbarkeit). Pada kurang lebih 1990 atau akhir 1980 -an Bank Dunia berkesimpulan, bahwa apapun dan berapapun "sumbangan" yang dikucurkan ke negara-negara Afrika (Sub-Sahara) pasti habis tanpa bekas. Persis seperti air yang dituangkan di atas gurun pasirnya yang panas. Fenomena ini disebut oleh Bank Dunia sebagai bad governance, artinya pengelolaan (Uang, sumberdaya) yang buruk sekali. Ini adalah euphemisme untuk, apalagi kalau bukan korupsi.
\end{abstract}

Kata kunci: Democratic governance, transparan, terbuka

\begin{abstract}
State / public management that is clean from corruption, collusion, nepotism, and management of state / public resources must be transparent, open, more than that every citizen is given access to participate in influencing the management of the way --participation. Public agencies need to be monitored, for example by Transparency International for global coverage or Indonesian Corruption Watch for national coverage. Now we have known a lot of "watchdog dogs" like that, including those covering the district / city or even village / village. Good governance is thus synonymous with transparency and participation - democratic governance. This includes the rule of law (rechtsstaatlichkeit and Berechenbarkeit). In approximately 1990 or the late 1980s the World Bank concluded, that anything and any "donations" disbursed to African countries (Sub-Saharan) must be exhausted without a trace. Just like water poured over a hot desert. This phenomenon is referred to by the World Bank as bad governance, meaning poor management (money, resources). This is euphemism for, especially if it's not corruption.
\end{abstract}

Keywords: Democratic governance, transparent, open

\section{BAB I PENDAHULUAN}

Birokrasi adalah pelayan demokrasi (lengkap dengan nilai-nilai turunannya) Birokrasi adalah, pada dasarnya, pelaksana kebijakan-kebijakan publik( aturan, hukum,undang-undang, porprov, pemkab/ pemkot, perdes). Ketika kebijakan publik telah dirumuskan secara demokratis, legitim secara politis, ketika itu pula birokrasi wajib menjalankannya "secara murni dan konsekuen". Itulah mandat,amanah yang diemban oleh setiap pegawai negeri, para pejabat, karyawan dan tenaga kontrakan maupun buruh harian lepas di instansi-instansi pemerintah. Dalam pengertian seperti ini, maka birokrasi haruslah taat-asas terhadap aturan-aturan yang dirumuskan oleh para politisi, baik mereka yang duduk di legislatif maupun eksekutif. Ketaat-asasan itu pun haruslah tertulis, terdokumentasi, formal. Konsekuensinya, memang, birokrasi akan bekerja secara kaku, infleksibel, impersonal, "tidak manusiawi".tetapi itulah nilai yang harus dibayar untuk nilai dasar yang lain: adil. 
Birokrasi yang kekeluargaan, yang gotong royong, dengan demikian, tidak bisa diterima, tidak masuk akal. Birokrasi adalah mesin, alat, instrumen untuk mengejar tujuan tujuan publik-yang dirumuskan oleh para warga melalui mekanisme demokratis. Pengejaran tujuan-tujuan publik tersebut, selain harus demokratik, juga harus dilakukan secara profesional agar supaya kinerja birokrasi-seperti telah disebut efektif dan efisien.

Sekarang konsep pengelolaan negara/ publik yang baik itu kita kenal dengan setidaknya sepuluh prinsip, yaitu:

1. Partisipasi: warga memiliki hak(dan mempergunakannya) untuk menyampaikan pendapat, bersuara dalam proses perumusan kebijakan publik, baik secara langsung maupun tidak langsung.

2. Penegakan hukum: hukum diberlakukan bagi siapapun tanpa pengecualian, hak asasi manusia dilindungi, sambil tetap diperhatikannya nilai-nilai yang hidup dalam masyarakat.

3. Transparansi: penyedian informasi tentang pemerintahan bagi publik dan dijaminnya kemudahan di dalam memperoleh informasi yang akurat dan memadai.

4. Kesetaraan: adanya peluang yang sama bagi setiap anggota masyarakat untuk beraktivitas/berusaha.

5. Daya tanggap: pekanya para pengelola instansi publik terhadap aspirasi masyarakat

6. Wawasan ke depan: pengelolaan masyarakat hendaknya dimulai dengan visi, misi dan strategi yang jelas.

7. Akuntabilitas: laporan para penentu kebijakan kepada para warga.

8. Pengawasan publik: terlibatnya warga dalam mengontrol kegiatan pemerintah, termasuk parlemen.

9. Efektivitas dan efisiensi: terselenggaranya kegiatan instansi publik dengan menggunakan sumberdaya yang tersedia secara optimal dan bertanggung jawab. Indikatornya antara lain: pelayanan mudah, cepat tepat dan murah.

10. Profesionalisme: tingginya kemampuan dan moral para pegawai pemerintah, termasuk parlemen.

Jadi, bukan hanya nilai-nilai kepublikan(demokrasi lengkap dengan nilai-turunannya), yang selama ini kita anggap baik dan kita usahakan untuk direalisasikan,yang dimengerti sebagai kandungan dari good governance, melainkan juga nilai-nilai administratif, manajerial (efektivitas, efisiensi, profesionalisme).

\section{BAB II PEMBAHASAN}

\section{Konsistensi kebijakan problematika}

Haruskah birokrasi selalu taatasas atas nama demokrasi, pertanyaan ini harus dijawab dengan "ya" konsistensi, tetapi ketika demokrasi itu tidak mewujud secara sempurna, sebagaimana telah kita rasakan selama lima tahun terakhir, khususnya sejak otonomisasi provinsi dan kabupaten/ kota per Januari. Ketika itu kita perlu meninjau kembali mandat birokrasi diatas.

Demokrasi dalam praktek kita memiliki setidaknya tiga kelemahan sebagai berikut:

a Proses demokrasi membutuhkan waktu yang lama, sedangkan kebutuhan/ tuntutan warga berkembang lebih pesat daripada kebijakan publik.

b. Para elit politik (legislatif maupun eksekutif) tidak selalu cerdas, dan tidak sedikit yang "kurang berpendidikan"

c. Wakil(legislatif) tidak selalu amanah, egois, tidak selalu mengusung kepentingan publik.

Dalam hal pertama, kepatuhan birokrasi terhadap kebijakan-kebijakan publik telah dirumuskan secara demokratik, mungkin saja tidak mencapai tujuan yang diharapkan. Bahkan bisa saja malah menimbulkan masalah. Hal seperti ini bisa disebabkan oleh kualitas intelektual(termasuk daya tanggap), wawasan ke depan, profesionalisme dari elite politik yang rendah, sehingga mereka tidak bisa berpikir proaktif: namun bisa pula bersumber dari kelangkaan perangkat pendukung, seperti perpustakaan bank data dan staf akademik.

Sedangkan dalam hal kebijakan sudah jelas elite politik yang terpilih secara demokratis pada akhirnya ternyata tidak memperjuangkan apapun kecuali kepentingan diri mereka pribadi dan keluarganya atau paling banter artinya,"Malpraktik" politik ini sudah pasti akan menghasilkan kebijakan-kebijakan publik yang sama sekali tidak mensejahterakan masyarakat secara keseluruhan. 
Terhadap kebijakan publik yang dibuat dengan cara, berlatar-belakang atau ber"asbabun nuzul" seperti itu, sudah pasti kepatuhan birokrasi hanyalah akan membawa negara/publik ke jurang kesengsaraan, setidaknya menimbulkan reaksi publik yang berusaha menghentikan implementasinya atau bahkan menegasikan kebijakannya. Jika demikian, apa yang dapat dilakukan apabila birokrasi demokratik tidak konsistensi. Ada dua kemungkinan yaitu :

Pertama, atas nama demokrasi, sebagaimana telah disinggung di atas, birokrasi tetap taat asas menjalankan kebijakan publik yang bermasalah, tersebut. Biarkan kebijakan itu diimplementasikan apa adanya dan sebagaimana harusnya menurut para policy maker. Biarkan dampak -buruknya terwujud dan dirasakan oleh publik. Dan biarkan publik bersuara, memprotes dan mendaulat para elite politik pilihan mereka sendiri itu. Birokrasi netral, hanya menjalankan perintah, tidak pernah bersalah, dia adalah alat demokratis.

Kedua, birokrasi mengerahkan kreativitasnya, melakukan diskresi, keluar dari jalur yang telah digariskan oleh politik (yang demokratis tetapi bermasalah). Kreativitas atau diskresi ini bukan penyimpangan dari kacamata hukum. Atau, kalaupun tindakan ini dianggap penyimpangan, dia bukanlah penyelewengan dari kacamata "etika". Ketika elit politik membuat kebijakan yang menyengsarakan publik, yang menodai misi demokrasi itu sendiri, maka tidak taat kepadanya bukanlah hal yang haram. Mungkin malah wajib, ketika politik tidak akan lagi responsif terhadap tuntutan publik yang baik, maka politik dapat dianggap tidak memiliki legitimasi lagi dan karena itu tidak perlu diikuti, termasuk tidak perlu dipatuhi oleh birokrasi. Raison d"etrenya, kalau istilah ini boleh dipakai, telah hilang.

Tetapi langkah seperti itu sangat debatable: artinya bagaimana kita dapat mengklaim bahwa suatu tuntutan yang diusung oleh sekelompok orang atau sebagian warga adalah tuntutan publik. Arti kedua, ukuran apa yang digunakan untuk menilai bahwa tuntutan publik tersebut, kalau memang itu tuntutan publik, adalah baik, menurut dari segi hukum,etika/moral.agama, tradisi, konvensi, yang mana tidak sesuai dengan hukum tetapi sesuai dengan moral, dan instansi mana yang berwenang mengambil keputusan akhir. Pengadilan umum, pengadilan agama, pengadilan tata usaha negara, diperlukan untuk membuat keputusan di instansi peradilan ini sementara persoalan membutuhkan penanganan yang optimal menurut hukum,segera mungkin.Ada setidaknya tiga alternatif jawaban yang dapat diajukan terhadap problema diatas. ]

Pertama, birokrasi diberi ijin untuk melakukan diskresi itu, namun harus segera melaporkannya kepada legislatif untuk di nilai. Jika memang diskresi birokrasi tersebut tepat, legislatif mengesahkannya: jika tidak tepat, legislatif menghentikannya tanpa sanksi apapun, kecuali jika diketahui bahwa diskresi tersebut dilakukan tidak untuk mengejar kepentingan publik melainkan pribadi. Namun alternatif ini agak sulit dipahami, mengingat bahwa sumber masalah ada pada legislatif sendiri.

Kedua, sistem perumusan kebijakan publik kita haruslah tidak saja membuka akses yang luas bagi segenap pilar masyarakat untuk berpartisipasi, melainkan juga perlu dilengkapi dengan mekanisme referendum atau mekanisme yang lain, yang memungkinkan publik merevisi kebijakan tersebut ketika mayoritas anggota legislatif dicurigai tidak lagi aspiratif terhadap publik mereka.

Ketiga, bersifat preventif, kebijakan publik tidak boleh dirumuskan oleh legislatif saja melainkan juga oleh seluruh pilar masyarakat (wakil rakyat, parlemen), melainkan oleh semua setiap pilar masyarakat tersebut dapat diwakili oleh beberapa orang saja, setiap pilar masyarakat tersebut dapat diwakili oleh beberapa orang saja, sesuai proporsi masing-masing.

Namun bukan dengan pemilihan wakil masing-masing melainkan dengan memilih secara acak/random. Mungkin ini terkesan rumit dan repot pelaksanaannya kita telah pandai melakukan quick count dalam memprediksi perolehan suara dalampemilu parlemen dan presiden belum lama ini. Dan sebagian hasilnya prediksinya dapat dikatakan cukup tepat. Pastilah kita bisa juga melakukan pemetikan wakil secara acak. Wakil-wakil inilah yang merumuskan kebijakan publik, dan hasilnya sedikit-banyaknya harus diadopsi oleh legisla- 
tif atau policy makers. Tentu saja mereka tidak dibiarkan bekerja sendirian, melainkan didampingi oleh teknokrat atau pakar yang relevan.Misalnya dalam merumuskan kebijakan pendidikan,dosen-dosen dari UNMAR diminta untuk menjadi pendamping, fasilitator atau narasumber: kebijakan birokrasi administrasi sosial dan publik politik didampingi oleh dosendosen fakultas sospol. Mekanisme seperti ini tampaknya lebih mudah dibayangkan untuk dilaksanakan oleh sistem birokrasi governance baik di pemerintahan daerah,kabupaten kecamatan,desa daripada oleh sistem negara.

\section{Ketidakmatangan politik}

Inkonsistensi pelaksanaan kebijakan (atau lack of implementation), apapun penyebabnya, menjadikan tidak adanya kepastian hukum. Ini menjadikan para pelaku kebijakan(dalam kasus ini terutama adalah awak bus dan penumpang), tidak punya pegangan yang jelas dalam berperilaku. Para awak bus, terutama bus gunung harta yang selama ini dirugikan dengan inkonsistensi tersebut, bahkan merasa powerless, tidak berdaya , melihat bus-bus bali menaikan penumpang di sepanjang jalan. Apalagi mereka juga menganggap bahwa para awak bus bali di beking oleh kekuatan (ekonomi maupun politik) tertentu. Tetapi, melihat latar-belakangnya, apakah pengekspresian rasa frustrasi seperti itu dapat diterima? Persoalan tidak terletak pada "dapat diterima" atau "tidak dapat diterima", melainkan pada kenyataan bahwa situasi semacam itu menunjukan belum matangnya perilaku politik mereka. Tentu saja ini menjadikan setiap kesepakatan kosong dari aspirasi salah satu pihak, dan hanya memuaskan kepentingan pihak lain. Dalam hal terakhir ini, ketidakmatangan politik melekat pada diri pembuat kebijakan. Pembuat kebijakan yang seharusnya bertindak sebagai"moderator" atau "wasit" berubah peran menjadi "pelayan" bagi sebuah kepentingan tertentu.

\section{BAB III PENUTUP}

Secara epilog berkesimpulan di atas dilakukan dengan asumsi, bahwa birokrasi adalah instrumen untuk mencapai tujuan-tujuan publik, mereka steril,taat asas, tidak memihak,impersonal seperti mesin. Asumsi ini kiranya tidak tepat, tidak realistis. Birokrasi berisi manusia, yang punya self dan vested interest. Namun memasukkan hal ini ke dalam diskusi hanya akan rumitnya pembahasan, jika bukan pesimisme.

\section{DAFTAR PUSTAKA}

Istilah good governance (untuk pengelolaan negara/publik) ini tanpaknya insfiratif sebagaimana goverment meniru online banking.

Lihat http://www.goodgovernance.or.id/ sitemap.asp, 22 januari 2004. ---. 2003. Bandingkan dengan Agus Dwiyanto dkk, reformasi tata pemerintahan dan otonomi Daerah, yogyakarta:pskk UGM.

Rekruitmen staf ahli bagi para anggota DPR sejak sekitar 2002 kiranya merupakan upaya untuk menambal kelemahan ini.

Seterusnya fungsi judikatif(pengawasan) pun tidak saja dimainkan oleh lembaga peradilan,melaikan oleh semua. Semua pilar mesyarakat melakukan pengawasan terhadap semua pilar(check and balances)

Bandingkan dengan peter C.Dienel, Die Planungszelle, eine Alternative zur Establishment-demokratie, Opladen: Westdeutscher Verlag 1997.

Reformasi Administrasi,bunga rampai pemikiran administrasi negara/publik,penerbit gava media,Dr.Samodra Wibawa.2005.

Jurnal ini dipersiapkan untuk jurnal cakrawaty tentang democratic governance in theory,transparansi,open good governance, dalam rangka Dies Natalis Fisipol UNMAR, Denpasar September 2020 